\title{
ZEOLITE AS A FACTOR IN THE IMPROVEMENT OF SOME REPRODUCTIVE TRAITS OF DAIRY COWS
}

\author{
S. Pešev ${ }^{1}$, Z. Ilić ${ }^{2}$ B. Milošević ${ }^{2}$ Z. Spasić ${ }^{2}$ B. Ristanović ${ }^{2}$ \\ ${ }^{1}$ FSH Agromil, Pojate, Republic of Serbia \\ ${ }^{2}$ Faculty of Agriculture Lešak, Republic of Serbia \\ Corresponding author: sasa.pesev@gmail.com \\ Original scientific paper
}

Abstract: Reproductive traits and health status in dairy cows are largely affected by diet quality. Natural zeolite has been successfully used in livestock production as a feed supplement for some types and categories of domestic animals. This experiment was conducted over a period of 15 months involving Domestic Spotted dairy cows. The test animals were assigned to three groups, each receiving different levels of supplemental zeolite. The control group comprised cows that received no zeolite supplement. Experimental groups I and II were fed rations supplemented with $4 \%$ and $2 \%$ zeolite, respectively. The reproductive traits studied included gestation length, length of service period, length of calving interval, calf body weight at birth and calf body weight at 90 days of age. The results obtained suggest that zeolite supplementation affects some reproductive traits, depending on the zeolite level present in livestock feed.

Key words: dairy cows, zeolite, service period, calf body weight

\section{Introduction}

Reproductive traits in dairy cows are largely affected by diet quality. Natural zeolite has been successfully used in livestock production as a feed supplement for some types and categories of domestic animals. Related studies in dairy cattle were conducted by Harvey et al. (1991), Neustroyev et al. (1995), Nešić (2000), Pešev et al. (2005) and Ilić et al. (2007).

Livestock feeds that contain mycotoxins affect not only reproductive performance, but also other traits in cattle. Harvey et al. (1991), Neustroyev et al. (1995), Ilić et al. (2005), Pešev et al. (2005) justify the use of zeolite in livestock feeds fed to lactating cows. 


\section{Materials and Methods}

This study involved 45 Domestic Spotted dairy cows. The test animals were assigned to 3 groups each comprising 15 animals and involving use of different levels of supplemental zeolite. The control group (C) received no zeolite supplement. Experimental group I (E-I) and Experimental group II (E-II) were fed rations i.e. compound feeds supplemented with $4 \%$ and $2 \%$ zeolite, (commerce name „Tufozel“" origin from Serbia) respectively.

„Tufozel" is a finely micronized thermally and technologically treated feed supplement that exhibits a highly selective adsorption capacity for mycotoxins. "Tufozel" is unharmful, insoluble, non-resorptive and leaves no residue in milk.

The trial was conducted at a farm in Veliki Šiljegovac.

The objective of this study was to perform a complex evaluation of the effect of different levels of supplemental "Tufozel" on reproductive traits in dairy cows.

\section{Results and Discussion}

Gestation length is a gene-governed breed characteristic. The analysis of this trait in all three groups of cows gave quite uniform results which are presented in Table 1.

Table 1. Duration of gravid period, days

\begin{tabular}{|c|c|c|c|c|c|c|c|c|}
\hline \multirow[b]{2}{*}{ Group } & \multirow[t]{2}{*}{$\mathrm{N}$} & \multirow{2}{*}{$X$} & \multirow{2}{*}{$S_{\bar{x}}$} & \multirow[t]{2}{*}{ SD } & \multirow[t]{2}{*}{$\mathrm{CV}(\%)$} & \multicolumn{2}{|c|}{ Variations } & \multirow[t]{2}{*}{ Fexp } \\
\hline & & & & & & $\min$ & $\max$ & \\
\hline E-I & 15 & 280.80 & 1.20 & 4.66 & 1.66 & 272 & 285 & \\
\hline E- II & 15 & 282.27 & 0.93 & 3.59 & 1.27 & 276 & 287 & $0.8^{\mathrm{NS}}$ \\
\hline $\mathrm{C}$ & 15 & 282.33 & 0.67 & 2.58 & 0.91 & 280 & 285 & \\
\hline
\end{tabular}

N.S. $-\mathrm{P}>0.05 ;{ }^{*}-\mathrm{P}<0.05 ; *^{*}$ - $\mathrm{P}<0.01 ; * * *-\mathrm{P}<0.001$

The highest average value for gestation length was obtained in control dairy cows that received no zeolite supplement. The shortest gestation period was found in Experimental group I that was fed compound feed supplemented with 4\% zeolite. The data presented in Table 1 show no statistically significant differences in gestation length $(\mathrm{P}>0.05)$.

Similar results were reported by Fiss and Wilton (1989), Kress et al. (1990), Perišić (1998) and Pěsev (2005). The results obtained in this study conform to those obtained by Spasić (1996) and Petrović (2000). Ilić et al. (2007) reported results that showed no statistical significance in gestation length during feed zeolite supplementation, their results being in agreement with those herewith presented. 
Service period refers to the calving-to-conception interval involving stabilization of the functions of reproductive organs in cows to enable unobstructed continuation of reproduction. The optimal service period length ranges from 60 to 90 days, resulting in one calving per year. Length of service period can be affected by external factors.

Table 2. Duration and variability of service period, days

\begin{tabular}{|l|c|c|c|c|c|c|c|c|}
\hline \multirow{2}{*}{ Group } & \multirow{2}{*}{$\mathrm{N}$} & $\bar{X}$ & $S_{-}$ & \multirow{2}{*}{$\mathrm{SD}$} & $\mathrm{CV}(\%)$ & Varia & tions & \multirow{2}{*}{ Fexp } \\
\cline { 1 - 4 } & & & & & & $\min$ & $\max$ & \\
\hline E-I & 15 & 70.93 & 12.86 & 49.80 & 70.20 & 42 & 240 & \\
\hline C & 15 & 84.53 & 10.72 & 41.53 & 49.13 & 54 & 180 & $31.40^{* *}$ \\
\hline
\end{tabular}

N.S. $-\mathrm{P}>0.05 ; *$ - $\mathrm{P}<0.05 ; * *$ - $\mathrm{P}<0.01 ; * * *-\mathrm{P}<0.001$

Table 2. presents the average length of service period and its variations in dairy cows. The E-I group of cows had an average length of service period of 70.93 days, showing variations between 42 and 240 days. The coefficient of variation was high $(70.20 \%)$, being the result of an exceptionally long service period lasting for 240 days.

The average length of service period in E-II group and control cows was 84.53 and 87.27 days, respectively. The best results in terms of length of service period were obtained in E-I cows group that received 4\% "Tufozel" supplement, followed by E-II group cows fed compound feeds supplemented with $2 \%$ "Tufozel". The longest service period was obtained in control cows that received compound feeds with no "Tufozel" supplementation. All average lengths of service periods were found to be within the range of optimal service period length.

Differences in service period length between the test groups were statistically very significant $(\mathrm{P}<0.01)$.

The results obtained comply with those reported by Gutic et al. (1997) and Perišić (1998). A somewhat longer service period was obtained by Hakana et. al. (1995) and Motyckka et al. (1997), and a considerably longer service period by Caput et al. (1989), Spasić (1996) and Petrović (2000). Ilić et al. (2007) show statistically very significant differences in length of service period between groups.

Calving interval is defined as the period between two consecutive calvings. According to Gutić (1988), the optimal length of calving interval ranges from 330 to 404 days or from 11 to 13 months. The average lengths of calving interval and their variations are given in Table 3. 
Table 3. Duration and variability of interval between calving, days

\begin{tabular}{|l|c|c|c|c|c|c|c|c|}
\hline \multirow{2}{*}{ Group } & \multirow{2}{*}{$\mathrm{N}$} & $\bar{X}$ & \multirow{2}{*}{$S_{-}$} & \multirow{2}{*}{$\mathrm{SD}$} & \multirow{2}{*}{$\mathrm{CV}(\%)$} & \multicolumn{2}{|c|}{ Varia } & \multicolumn{2}{|c|}{ tions } & \multirow{2}{*}{ Fexp } \\
\cline { 1 - 4 } & & & & & & $\min$ & $\max$ & \\
\hline E-I & 15 & 351.73 & 12.44 & 48.20 & 13.70 & 320 & 512 & \\
\hline E- II & 15 & 367.20 & 11.00 & 42.60 & 11.60 & 334 & 465 & $0.98^{\mathrm{NS}}$ \\
\hline C & 15 & 369.60 & 3,53 & 13.68 & 3.70 & 348 & 387 & \\
\hline
\end{tabular}

N.S. $-\mathrm{P}>0.05 ;{ }^{*}-\mathrm{P}<0.05 ;{ }^{* *}-\mathrm{P}<0.01 ; * * *$ - $\mathrm{P}<0.001$

The average value for calving intervals in all groups of cows was within the optimal range. No statistically significant differences in this trait were observed between the groups $(\mathrm{P}>0.05)$.

The research conducted by Ilić et al. (2007) showed compliance with this study in terms of length of calving period across groups as well as in terms of indicators of statistical significance. Similar results were obtained by Gutić et al. (1997) and Perišić (1998). A somewhat longer calving interval was reported by Caput et al. (1989) and Petrović (2000), whereas considerably higher values for length of calving interval were obtained by Spasić (1996).

Calf body weight was analyzed both at birth and at 90 days upon birth. It is dependent upon a number of factors. Calf body weight at birth depends on breedspecific predispositions as well as on environmental conditions. The major factors affecting calf weight after birth include breed, calf sex, type of birth, age of dam, dry period length and nutrition. Nutrition is a powerful factor that may result in larger calves, although calf size is not always an advantage as in the case of firstcalving dams. Calf size is also largely affected by the sire selected for use in insemination. The average calf body weight at birth and related variations are presented in Table 4.

Table 4. Weights of calves at the moment of delivery, $\mathrm{kg}$

\begin{tabular}{|l|c|c|c|c|c|c|c|c|}
\hline \multirow{2}{*}{ Group } & \multirow{2}{*}{$\mathrm{N}$} & $\bar{X}$ & \multirow{2}{*}{$S_{-}$} & \multirow{2}{*}{$\mathrm{SD}$} & \multirow{2}{*}{$\mathrm{CV}(\%)$} & \multicolumn{2}{|c|}{ Variations } & \multirow{2}{*}{ Fexp } \\
\cline { 1 - 3 } & & & & & & $\min$ & $\max$ & \\
\hline E-I & 15 & 43.73 & 1.48 & 5.72 & 13.09 & 38 & 60 & \\
\hline E- II & 15 & 47.90 & 1.35 & 5.24 & 10.93 & 40 & 60 & \multirow{2}{*}{$7.69^{* * *}$} \\
\hline
\end{tabular}

N.S. $-\mathrm{P}>0.05 ;{ }^{*}-\mathrm{P}<0.05 ; *_{-} \mathrm{P}<0.01 ; *^{* *}-\mathrm{P}<0.001$

The average calf body weight in E-I group cows was $43.73 \mathrm{~kg}$, with the coefficient of variation being $13.09 \%$. E-II group had an average calf body weight of $47.90 \mathrm{~kg}$. Calf body weight in this group of cows was more uniform than in the other two groups. The body weights of control calves were quite non-uniform. The average calf body weight in this group was $39.73 \mathrm{~kg}$, ranging from $35 \mathrm{~kg}$ to $60 \mathrm{~kg}$. Differences in calf body weight at birth between the groups were statistically very significant $(\mathrm{P}<0.01)$. Calf body weight at 90 days of age is presented in Table 5 . 
Table 5. Weights of calves in the first 3 months of age $(\mathrm{kg})$

\begin{tabular}{|c|c|c|c|c|c|c|c|c|}
\hline \multirow{2}{*}{ Group } & \multirow{2}{*}{$\mathrm{N}$} & \multirow{2}{*}{$\bar{X}$} & \multirow{2}{*}{$S_{-}$} & \multirow{2}{*}{ SD } & \multirow{2}{*}{$\mathrm{CV}(\%)$} & \multicolumn{2}{|c|}{ Varia tions } & \multirow{2}{*}{ Fexp } \\
\hline & & & & & & $\min$ & $\max$ & \\
\hline E-I & 15 & 141.40 & 1.75 & 6.79 & 4.80 & 135 & 155 & \\
\hline E- II & 15 & 145.86 & 1.26 & 4.89 & 3.35 & 139 & 155 & $6.34^{* *}$ \\
\hline $\mathrm{C}$ & 15 & 138.73 & 1.21 & 4.59 & 3.38 & 130 & 145 & \\
\hline
\end{tabular}

The highest body weight in the first 3 months of age was attained by E-II group calves $(145.86 \mathrm{~kg})$, followed by E-I group (141.40 kg) and C group calves $(138.73 \mathrm{~kg}$,).

The average body weight gain was $1.08 \mathrm{~kg}, 1.09 \mathrm{~kg}$ and $1.10 \mathrm{~kg}$ in E-I, E-II and control groups calves, respectively. This trait showed a statistically very significant difference between the groups $(\mathrm{P}<0.01)$.

Calf weight was found to be lower in studies by Kress et al. (1990), Alpan et al. (1997), Perišić (1998), Petrović (2000) and Pešev (2002). Nešić (2000) used diets supplemented with $0.5 \%$ zeolite in calves during the first 90 days of age and obtained a slightly lower daily weight gain as compared to the calves in the present study that received 2 and 4\% zeolite. Ilić et al. (2007) obtained statistically non-significant differences in calf weight.

\section{Conclusion}

Gestation length showed the highest average value in the control group of dairy cows that received no zeolite supplement. The shortest gestation period was obtained in Experimental group I that was fed compound feed supplemented with $4 \%$ zeolite ("Tufozel"). The study showed no statistically significant differences in gestation length $(\mathrm{P}>0.05)$.

The control group cows had an average length of service period of 87.27 days, which was the longest service period in this research. The best results in terms of service period were obtained in E-I group cows that received $4 \%$ zeolite as a compound feed supplement. The average lengths of service periods were within the optimal range. Differences in service period length between groups were statistically very significant $(\mathrm{P}<0.01)$. The average calving interval value in all groups was within the optimal range. This trait showed no statistically significant differences between groups $(\mathrm{P}>0.05)$.

The average body weight of E-I group and E-II group calves was $43.73 \mathrm{~kg}$ and $47.90 \mathrm{~kg}$, respectively, with the latter group exhibiting higher uniformity of body weight as compared to the other two groups. The body weights of control 
calves were quite non-uniform. Differences in calf body weight at birth between groups were statistically very significant $(\mathrm{P}<0.01)$.

The highest body weight in the first 3 months of age was attained by E-II group calves $(145.86 \mathrm{~kg})$, followed by E-I group $(141.40 \mathrm{~kg})$ and $\mathrm{C}$ group calves $(138.73 \mathrm{~kg})$. This trait showed a statistically very significant difference between groups $(\mathrm{P}<0.01)$.

Zeolite ("Tufozel") supplementation was found to affect reproductive traits in dairy cows.

\title{
Acknowledgment
}

Research was financed by the Ministry of Education and Science, Republic of Serbia, project TR 31001.

\section{Zeolit kao faktor poboljšanja nekih reproduktivnih osobina kod krava muzara}

\author{
S. Pešev, Z. Ilić, B. Milošević, Z. Spasić, B. Ristanović
}

\section{Rezime}

Dužina bremenitosti pokazala je najveću prosečnu vrednost kod kontrolne grupe krava muzara koje nisu dobijale zeolit. Najkraću dužinu bremenitosti imala je prva ogledna grupa krava koja je konzumirala krmnu smešu sa 4\% zeolita (“Tufozel”). Istraživanja su pokazala da nije bilo statistički značajne razlike u pogledu dužine bremenitosti $(\mathrm{P}>0,05)$.

Kontrolna grupa krava imala je prosečnu dužinu servis perioda od 87,27 dana što predstavlja najduže trajanje servis perioda u ovim istraživanjima. Razlike $\mathrm{u}$ trajanju servis perioda imeđu grupa su statistički vrlo značajne $(\mathrm{P}<0,01)$.

Prosečna vrednost međutelidbenih intervala kod svih grupa krava nalazila se $\mathrm{u}$ opsegu optimalnih vrednosti. Razlike $\mathrm{u}$ ispoljenosti nivoa statističke značajnosti među grupama, kod ove osobine, nisu zabeležene $(\mathrm{P}>0,05)$.

U I-O grupi krava dobijena je prosečna masa teladi od $43,73 \mathrm{~kg}$, dok je $\mathrm{u}$ II-O grupi krava prosečna telesna masa teladi iznosila $47.90 \mathrm{~kg}$. U ovoj grupi krava je bila ujednačenija masa teladi u poređenju sa ostale dve grupe. Kontrolna grupa krava dala je telad sa dosta neujednačenom telesnom masom. Razlike u masi teladi pri rođenju među grupama su statistički vrlo značajne $(\mathrm{P}<0,01)$.

Najveću telesnu masu sa 3 meseca starosti postigla su telad II-O grupe $(145,86 \mathrm{~kg})$, zatim I-O grupe $(141,40 \mathrm{~kg})$, dok su najlakša telad bila u K-grupi 
$(138,73) \mathrm{kg}$. Kod ove karakteristike postoji statistički vrlo značajna razlika među grupama $(\mathrm{P}<0,01)$.

Dodavanje minerala zeolita, u vidu preperata ("Tufozel"), imalo je pozitivan uticaj na reproduktivne osobine krava.

\section{References}

ALPAN O., ERTUGRUL O., UMAY M., BILKI A., BULMUS S. (1997): Improvement of beef production traits of Southern Anatolian red through crossings with Simmental bulls. Book of Abstracts of the 48th Annual Meeting of the European Association for Animal Production, Vienna, Austria, 25-28 August.

FISS F.C., WILTON J.W. (1989): Effects of breeding syistem, cow weight and milk yield on reproductive perforrmannce in bref cattle. Journal of Animal Science, 67, 7, 1714-1721.

GUTIĆ M., BOGOSAVLJEVIĆ-BOŠKOVIĆ S., PETROVIĆ M. (1997): Prilog poznavanju povezanosti trajanja perioda zasušenja, servis perioda i indeksa plodnosti krava simentalske rase. Agroznanje, I, 253-260, Banja Luka.

HAKANA I.A., KARMANOVA E.P., BOLGOV A.E., MAKAROVA V.E. (1995): Effect of milk production selection on cow reproductive performance. 46 Annual Meeting of the EAA, Abs, Proque.

HARVEY B.R., PHILLIPS D.T., ELLIS J.A.,KUBENA F.L., HUFF E.W., PETERSON H.D. (1991): Effect on aflatoxin M1 residues in milk by adition of Rydrated sodium Calcium aluminosilicate to aflatoksin contaminated diets of dairy cows. Amar. J. Vet. Res., 52, 1556.

ILIĆ Z., PEŠEV S., SIMEONOVA V., MILOŠEVIĆ B., SPASIĆ Z. (2005): The influence of zeolite type tufozel on productive characteristics of dairy cows. Biotechnology in Animal Husbandry, 21, 5-6, 25-30.

ILIĆ Z., PEŠEV S., MILENKOVIĆ M., MILOŠEVIĆ B. (2007): Impact on the zeolite usage in diary cows nutrition to their health characteristics. Biotechnology in Animal Husbandry, 23, 5-6, 25-33.

ILIĆ Z., PEŠEV S., MILENKOVIĆ M., SPASIĆ Z. (2007): Efekat upotrebe zeolita $\mathrm{u}$ ishrani krava muzara na neke proizvodne i reproduktivne osobine. Monografija, „Unapređenje poljoprivredne proizvodnje na Kosovu i Metohiji“, 317-325.

KRESS D.D., DOORNOBOS E.D., ANDERSON C.D. (1990): Performance of crosses omong xereford, angus and simmental cattle with diferent levels of simental breeding. IV Maternal heterosis and calf production by two-year-old dams, Journal of Animal Science, 68, 1, 54-63.

MOTYČKA J., SUCHAN V., DOLEŽAL O. (1997): Comparison of milk production between imported Ppim Holstein and Montbeliarde animals and Czech 
Fleckvieh. Book of Abstracts of the 48 th Annual Meeting of the European Association for Animal-Ppoduction, 25-28th August, Vienna, Austria.

NEŠIĆ S. (2000): Upotreba prirodnog zeolita u obrocima za telad i krave u laktaciji. Magistarska teza, Poljoprivredni fakultet, Beograd-Zamun.

NEUSTROYEV M.P., TARABUKINA N.P. (1995): Perspectives of zeolite use in veterinary medicine. International Simposium and Exhibition on Natural Zeolites, Sofia, 114-115.

PERIŠIĆ P. (1998): Reproduktivne i proizvodne osobine različitih genotipova krava simentalske rase. Magistarska teza, Poljoprivredni fakultet, Beograd-Zemun. PEŠEV S., ILIĆ Z., SIMEONOVA VALENTINA, MILOŠEVIĆ B., SPASIĆ Z. (2005): The influence of zeolite type tufozel on reproductive characteristics of dairy cows. Biotechnology in Animal Husbandry, 21, 5-6, 19-24.

PETROVIĆ M. (2000): Ispitivanje dugovečnosti ,proizvodnje mleka i mlečne masti krava simentalske rase. Magistarska teza, Poljoprivredni fakultet, BeogradZemun.

URBAN F., BOUŠKA J., BARTON L. (1998): Diversification of the breed structure in cattle population of the Czech Republic. Biotehnologija u stočarstvu, 14, 5-6, 43-50.

VAŽIĆ B., KASAGIĆ D., DRINIĆ M.., MATARUGIĆ D., MARKOVIĆ Z. (2005): Proizvodnja mleka kod kontrolisanih stada simentalske rase u Republici Srpskoj. Agro-knowledge Journal, University of Banjaluka, Faculty of Agriculture, 6, 2, 107-113. 